\title{
COMMENTS
}

\section{PERSONAL JURISDICTION IN TRIBAL COURTS}

\author{
DAVID A. CASTLEMAN ${ }^{\dagger}$
}

\section{INTRODUCTION}

Long before the first European immigrants set foot on American shores, Indian tribes had systems to administer justice. ${ }^{1}$ Long after the federal government had effectively subjugated tribal governments, Congress passed the Indian Reorganization Act $^{2}$ to encourage tribes to "organize Western-style governments." Formal court systems, "a relatively recent development in Indian Country," ${ }^{4}$ are essential components of a functioning Western-style government. These court systems have grown substantially over the past three decades. ${ }^{5}$ In 1974, the American Indian Law Training Program began publishing the In-

${ }^{\dagger}$ A.B. 2001, Dartmouth College; J.D. candidate 2006, University of Pennsylvania Law School. This Comment is dedicated to my parents, Bruce and Penny, for supporting this and every other endeavor. Thanks to the editors of the Law Review, especially Lauren Fox and Abby Wright, for their careful and insightful editing. I owe a special debt of gratitude to Professor Catherine Struve, in whose seminar I began this project, for patiently reviewing multiple drafts of this Comment. While I am grateful to all those who have suggested improvements to this Comment, all opinions and errors are mine alone.

${ }^{1}$ See National Tribal Justice Resource Center, Tribal Court History, http://www.tribalresourcecenter.org/tribalcourts/history.asp (last visited Mar. 7, 2006) ("Since time immemorial, Native American and Alaska Native tribes have been keeping the peace and administering justice in their homelands through the use of their own ancient laws, traditions and customs.").

I use the term "Indian" rather than "Native American" because the former is the term commonly used in the law. Cf. Catherine T. Struve, Raising Arizona: Reflections on Sovereignty and the Nature of the Plaintiff in Federal Suits Against States, 61 MONT. L. REv. 105,110 n.21 (2000) (explaining the author's choice to use the term "Indian" over "Native American").

${ }^{2}$ Pub. L. No. 73-383, 48 Stat. 984 (1934) (codified as amended at 25 U.S.C. $\S \S$ 461-479 (2000)).

${ }^{3}$ Nell Jessup Newton, Tribal Court Praxis: One Year in the Life of Twenty Indian Tribal Courts, 22 AM. INDIAN L. REV. 285, 291 (1998).

${ }^{4}$ National Tribal Justice Resource Center, supra note 1.

${ }^{5}$ See Newton, supra note 3, at 291 (indicating that the creation of tribal courts has "accelerated greatly"). 
dian Law Reporter to collect "on a monthly basis all current developments in the field of Indian law." ${ }^{6}$ It was not until 1983 that the reporter also began to publish tribal court cases. ${ }^{7}$ In 2004, the Indian Law Reporter published eighty-two tribal court decisions (mostly appellate cases), ${ }^{8}$ which is roughly as many as the number of formal written opinions issued annually by the United States Supreme Court. ${ }^{9}$ The development and growth of tribal court systems ${ }^{10}$ is a key element of tribal sovereignty. For the federal government to remain committed to its current policy of promoting tribal self-government, it must support these growing systems.

For tribal court systems to be effective, they must adjudicate the disputes that legitimately come before them. This requires that a tribal court have the power to exercise jurisdiction over both the dispute and the parties. Although federal courts have paid close attention to the limits of tribal subject matter jurisdiction, personal jurisdiction is often overlooked. ${ }^{11}$ Because tribal courts have the power to "enter[] ... multi-million dollar judgment[s],"12 whether tribal courts have personal jurisdiction over the parties before them is a question of supreme importance to potential litigants.

In this Comment, I argue that the Indian Civil Rights Act of 1968 (ICRA), ${ }^{13}$ via its due process clause, limits tribal courts' exercise of personal jurisdiction over nonconsenting defendants. The external limitations on tribal jurisdiction in general come from federal law. For instance, in Strate v. A-1 Contractors, the Supreme Court severely curtailed tribal court subject matter jurisdiction over a nonmember to cases where she has entered into a consensual relationship with the tribe, or where the political integrity, economic security, or health and welfare of the tribe is at stake. ${ }^{14}$

${ }^{6}$ Introduction to 1 Indian L. Rep. ii, ii (1974).

${ }^{7}$ See Introduction to 10 Indian L. Rep. 6001, 6001 (1983) (announcing "a new section devoted to the publication of selected tribal court and tribal appellate court decisions").

31 Indian L. Rep. 6001, 6001-6161 (2004).

${ }^{9}$ See The Justices' Caseload, http://www.supremecourtus.gov/about/justicecaseload.pdf (last visited Mar. 21, 2006) ("Formal written opinions are delivered in 80-90 cases.").

${ }^{10}$ For an excellent analysis of the growth of the tribal court system generally, see Newton, supra note 3, at 291-94.

${ }^{11}$ See infra Part III (discussing how federal courts have avoided personal jurisdiction questions when evaluating the proper extent of tribal jurisdiction).

${ }^{12}$ William C. CANBy, JR., AMERican INDian LAW in A NutShell 187 (3d ed. 1998).

${ }^{13}$ Pub. L. No. 90-284, 82 Stat. 73, 77-78.

${ }^{14} 520$ U.S. 438, 453 (1997) (extending Montana v. United States, 450 U.S. 544, 565-67 (1981), which created this approach to limit regulatory jurisdiction); see also in- 
The limiting of tribal power by the Supreme Court has been extremely controversial, especially because the plenary power doctrine vests in Congress the power to regulate Indian tribes. ${ }^{15}$ Even if the plenary power doctrine does not prevent the Supreme Court from acting where Congress has remained silent, the doctrine does require deference to Congress where it has acted. ${ }^{16}$ Thus, if Congress enacts a statute that defines the scope of tribal power, then the federal courts must follow that statute, even if they had developed law to the contrary. For instance, in 1990, the Supreme Court created a new rule divesting tribes of their criminal jurisdiction over nonmember Indians, despite the absence of action by Congress. ${ }^{17}$ Congress soon thereafter "fixed" this problematic holding by legislating that, to the contrary, tribes do have criminal jurisdiction over nonmember Indians. ${ }^{18}$

Unlike the area of tribal court subject matter jurisdiction, where Congress has not acted, Congress has acted in the area of tribal court personal jurisdiction by passing the due process clause of the ICRA. ${ }^{19}$ Both the text and the legislative history of the ICRA indicate that the ICRA's due process clause should be interpreted similarly to the Fourteenth Amendment's ${ }^{20}$ and in accordance with the modern conception of personal jurisdiction first announced in International Shoe Co. $v$. Washington. $^{21}$ Furthermore, interpreting tribal personal jurisdiction using International Shoe is not merely a theoretical possibility. Some tribal courts, even in prominent cases, have shown a willingness to apply federal due process precedent in interpreting their own jurisdictional statutes. ${ }^{22}$

fra notes 45-47 and accompanying text (discussing the distinctions between nonIndians and nonmembers). While Strate applied only to non-Indian land within the reservation, 520 U.S. at 453-54, the Supreme Court later virtually obliterated the distinction between Indian and non-Indian land within the reservation in Nevada v. Hicks, 533 U.S. 353 (2001).

${ }^{15}$ See infra notes 157-62 and accompanying text (discussing the roots of the plenary power doctrine).

${ }^{6}$ See infra notes 159-60 and accompanying text (conceptualizing the plenary power doctrine as requiring deference to Congress in Indian affairs).

${ }^{17}$ Duro v. Reina, 495 U.S. 676, 684-88 (1990).

18 See infra note 135 (discussing the "Duro fix").

${ }^{19} 25$ U.S.C. $\$ 1302(8)(2000)$.

${ }^{20}$ U.S. CONST. amend. XIV, § 1.

21326 U.S. 310, 320 (1945) (limiting personal jurisdiction based on the Due Process Clause of the Fourteenth Amendment); see also Helicopteros Nacionales de Colom. v. Hall, 466 U.S. 408, 413-19 (1984) (same).

${ }^{22}$ See Newton, supra note 3 , at 323 ("There appears to be a consensus among tribal courts that in analyzing the extent to which a tribe's exercise of personal jurisdiction is 
However, when dealing with the law of tribal courts, simply defining the source and scope of the court's jurisdiction is only the first step of the analysis; outlining the scope of federal review is the second step. In Santa Clara Pueblo v. Martinez, using the now-antiquated Cort v. Ash analysis, ${ }^{23}$ the Supreme Court refused to imply a federal cause of action to allow plaintiffs to enforce the ICRA outside of tribal court. $^{24}$ Ten years later, in National Farmers Union Insurance Cos. $v$. Crow Tribe of Indians, the Supreme Court held that federal law governs tribal court jurisdiction, and thus an action to challenge tribal court jurisdiction was a federal question. ${ }^{25}$ However, National Farmers only concerned subject matter jurisdiction, which was not governed by any federal statute. Although Martinez is distinguishable, the question remains whether National Farmers will be extended to disputes over personal jurisdiction. The Supreme Court should not, and most likely would not, find an implied cause of action to enforce the ICRA as it applies to the exercise of personal jurisdiction by tribal courts. Under the Court's current Alexander v. Sandoval analysis, ${ }^{26}$ which is substantially more restrictive than the Cort test on which the Martinez Court relied, the Court is unlikely to allow litigants a private right of action to challenge personal jurisdiction in tribal courts.

This Comment proceeds in four parts. In Part I, I briefly discuss the jurisdictional landscape. In Part II, I contend that the ICRA limits tribal courts' personal jurisdiction. In Part III, I survey how some tribal courts have incorporated constitutional concepts of personal jurisdiction into their own jurisprudence. In Part IV, I argue against creating a federal cause of action to directly challenge the personal jurisdiction of tribal courts.

\section{THE JURISDICTIONAL LANDSCAPE}

Successfully navigating the quagmire of tribal jurisdiction would require a guidebook far beyond the scope of this Comment. In this

\footnotetext{
consistent with due process . . . the courts will interpret due process by reference to the United States Supreme Court's precedents.”).

${ }^{23} 422$ U.S. 66,78 (1975).

${ }^{24} 436$ U.S. 49,59 (1978).

${ }^{25} 471$ U.S. 845, 852-53 (1985) (construing 28 U.S.C. $§ 1331$ (1982)); see also infra notes 128-31 and accompanying text (discussing the implications of National Farmers).

${ }^{26} 532$ U.S. 275, 286-87 (2001) ("The judicial task is to interpret the statute Congress has passed to determine whether it displays an intent to create not just a private right, but also a private remedy. Statutory intent on this latter point is determinative." (internal citations omitted)).
} 
Part, however, I will briefly set the stage for the rest of my argument. First, I will review the standards for subject matter and personal jurisdiction in federal and state courts. Then, I will lay out the basics of jurisdiction in tribal court.

\section{A. The Jurisdiction of Federal and State Courts ${ }^{27}$}

Federal courts are courts of limited subject matter jurisdiction and may only adjudicate matters over which they have been explicitly granted jurisdiction by both the Constitution and federal statute. ${ }^{28}$ "The practical effect of this proposition is that there is a presumption against federal jurisdiction: whereas the ability to hear a case is presumed in state courts of general jurisdiction, in the federal system the existence of subject matter jurisdiction must be demonstrated at the outset...." ${ }^{29}$ Additionally, although state courts are competent to hear actions that arise under federal law, ${ }^{30}$ in such cases Congress may encourage, or even require, federal jurisdiction. ${ }^{31}$

Of course, having jurisdiction over the subject matter of an action is only half of the picture. The court "also must have jurisdiction over the persons or property involved in the action." ${ }^{32}$ In order for a court to obtain personal jurisdiction over a nonconsenting defendant, it must have the authority under state law to do so, and the exercise of such jurisdiction must not violate constitutional due process requirements. While state laws ${ }^{33}$ vary, some states have enacted long-arm stat-

${ }^{27}$ This section is by no means intended to be a comprehensive summary exploring all of the subtleties of jurisdiction, but rather is intended to be a quick overview to set up the unique challenges presented by tribal courts' jurisdiction.

${ }^{28}$ JACK H. Friedenthal ET AL., Civil Procedure $§ 2.2$ (2d ed. 1993).

${ }^{29} I d$.

${ }^{30}$ See Tafflin v. Levitt, 493 U.S. 455, 458 (1990) (“[S] tate courts have inherent authority ... to adjudicate claims arising under the laws of the United States.").

${ }^{31}$ Congress may encourage federal jurisdiction through the removal procedure, which generally allows either party to choose the federal forum. See 28 U.S.C. $§ 1441$ (2000) (allowing, with some restrictions, a defendant to remove from state court to federal court an action over which the federal court has subject matter jurisdiction). Congress may also mandate the federal forum in some cases. See, e.g., 28 U.S.C. $§ 1333$ (2000) ("The district courts shall have original jurisdiction, exclusive of the courts of the States, of [admiralty and prize cases].”); see also The Moses Taylor, 71 U.S. (4 Wall.) 411, 429-30 (1867) (permitting Congress to allow a federal claim to be heard exclusively in federal court).

32 FRIEDENTHAL ET AL., supra note $28, \S 3.1$.

33 In federal court, the source of the personal jurisdiction law may come from the state in which the court sits, from the peculiarities of the statute creating the cause of action, or from some other provision. Id. $\$ 3.18$; see also FED. R. CIV. P. 4 (k) (laying out the federal rules of perfecting jurisdiction over a defendant). 
utes that permit their courts to acquire jurisdiction to the full extent that due process allows. ${ }^{34}$ The constitutional limitations on personal jurisdiction come from the Due Process Clauses of the Fifth and Fourteenth Amendments. ${ }^{35}$ Due process requires either actual presence ${ }^{36}$ or minimum contacts between the defendant and the forum state. ${ }^{37}$ Having briefly summarized the jurisdictional standards in federal and state courts, I turn now to the peculiarities of jurisdiction in tribal courts.

\section{B. The Jurisdiction of Tribal Courts}

Two centuries ago, Chief Justice John Marshall declared that Indian tribes are "domestic dependent nations," scribed by the Supreme Court as its "traditional understanding of the tribes' status." ${ }^{39}$ In 2004, in United States v. Lara, the Supreme Court held that a tribe acted as a separate sovereign distinct from the United States when it exercised its criminal jurisdiction over a nonmember Indian. ${ }^{40}$ The Court has also recognized "the plenary power of Congress over the affairs of native Americans" ${ }^{41}$ stemming from the Indian Commerce Clause. ${ }^{42}$ It might be tempting to think that the law of the sovereign should determine the jurisdiction of its courts. ${ }^{43}$ However, because the tribes are under the control of the federal government, the scope of tribal court jurisdiction is also a matter of federal law.

34 FRIEDENTHAL ET AL., supra note $28, \S 3.12$. In any case, this Comment is concerned with how the Constitution limits jurisdiction and not with the provisions that initially create such jurisdiction.

${ }^{35}$ U.S. Const. amend. V (limiting federal power); U.S. CONST. amend. XIV, § 1 (limiting state power).

36 See, e.g., Burnham v. Superior Court, 495 U.S. 604, 619 (1990) (opinion of Scalia, J.) (holding that if a nonresident defendant is served while actually present in the forum state, the exercise of jurisdiction over her does not violate due process).

37 Int'l Shoe Co. v. Washington, 326 U.S. 310 (1945). Determining exactly how much contact is sufficient depends on the facts of an individual case, and is beyond the scope of this discussion.

38 Cherokee Nation v. Georgia, 30 U.S. 1, 17 (1831).

${ }^{39}$ United States v. Lara, 541 U.S. 193, 204 (2004).

${ }^{40}$ See $i d$. at 210 (holding that because the tribe acted as a separate sovereign, criminal prosecutions for the same crime by both the tribe and the federal government did not violate the Double Jeopardy Clause).

${ }^{41}$ Rice v. Cayetano, 528 U.S. 495, 529 \& n.2 (collecting cases recognizing the plenary power of Congress).

${ }^{42}$ U.S. CONST. art I, $\$ 8$, cl. 3 .

${ }^{43}$ See, e.g., U.S. CONST. art III (delineating the maximum jurisdictional limits of the federal courts). 
Furthermore, the existence of tribal court jurisdiction may turn on the legal status of the parties in the dispute. ${ }^{44}$ Broadly speaking, this concept is not peculiar to tribal courts; for instance, the existence of subject matter jurisdiction in federal court may turn on the citizenship of the parties. ${ }^{45}$ In Indian law, there are two distinctions that may be relevant, depending on the jurisdictional issue: whether someone is an Indian or a non-Indian, and whether someone is a member or a nonmember of a particular tribe. An Indian is merely someone who "(1) ha[s] some Indian blood, and (2) [is] regarded as an Indian by his or her community." ${ }^{46}$ However, an Indian may also be a member of a particular tribe, which generally means that she is enrolled in that tribe. $^{47}$ Thus, for tribal jurisdictional purposes, there are three classes of person that are relevant: non-Indian, Indian nonmember, and member.

Having defined these terms, I now turn to the $\$ 64,000$ question: Under what circumstances does a tribal court have the power to exercise jurisdiction over a matter or a party? One might think that, like their state court counterparts, tribal courts should be courts of general jurisdiction. ${ }^{48}$ However, the Supreme Court recently held in $\mathrm{Ne}$ vada $v$. Hicks that tribal courts are not courts of general jurisdiction, because their "inherent adjudicative jurisdiction over nonmembers is at most only as broad as its legislative jurisdiction." ${ }^{49}$ Such legislative

${ }^{44}$ The ownership status of the land may be relevant as well, although it is unclear how that will enter the mix after the Supreme's Court decision in Hicks. Nevada v. Hicks, 533 U.S. 353, 359-60 (2001); see also Melissa L. Tatum, A Jurisdictional Quandary: Challenges Facing Tribal Governments in Implementing the Full Faith and Credit Provisions of the Violence Against Women Acts, 90 Ky. L.J. 123, 163 (2001) ("What is now clear after Hicks is that Montana's general rule preempting tribal civil jurisdiction over nonmembers applies throughout Indian Country, with land status used only as a factor in determining whether one of the Montana exceptions has been met. What is not clear, however, is the way in which land status will factor into this analysis.").

${ }^{45}$ See 28 U.S.C. $\$ 1332$ (2000) (requiring that the parties not be citizens of the same state in order for the court to have jurisdiction under that provision).

${ }^{46}$ CANBY, supra note 12 , at 187.

${ }^{47} I d$. at 8-9.

48 See, e.g., Robert N. Clinton, There Is No Federal Supremacy Clause for Indian Tribes, 34 ARIZ. ST. L.J. 113, 205-35 (2002) (arguing that federal courts have been usurping the proper jurisdiction of the tribal courts, which should be broad); Moran v. Council of the Confederated Salish \& Kootenai Tribes, 22 Indian L. Rep. 6149, 6154-56 (C.S. \& K.T. Ct. App. 1995) (holding, pre-Hicks, that the tribal law created the court to be one of general jurisdiction).

${ }^{49} 533$ U.S. at 367 . While the Court's statement in Hicks may sound relatively innocuous, restricting adjudicative jurisdiction to "legislative jurisdiction" is a far greater limit than is placed on federal and state courts. Consider a run-of-the-mill $\$ 150,000$ tort dispute between two diverse parties. Even assuming the federal government has 
or regulatory jurisdiction over nonmembers was limited in Montana $v$. United States to situations where the nonmember has entered into a consensual relationship with the tribe or where the political integrity, economic security, or health and welfare of the tribe is at stake. ${ }^{50}$ In Strate v. A-1 Contractors, the Supreme Court limited tribal adjudicatory jurisdiction over nonmembers to the same two Montana exceptions. ${ }^{51}$

Dissenting from the Court's holding in Hicks, Justice Stevens argued, "Absent federal law to the contrary, the question whether tribal courts are courts of general jurisdiction is fundamentally one of tribal law. ${ }^{, 52}$ Responding to this statement, the majority noted that Strate limited subject matter jurisdiction and that "even courts of limited subject-matter jurisdiction [can be said to] have general jurisdiction over those subjects that they can adjudicate." ${ }^{, 53}$ Assume for a moment that a case involving a nonmember satisfied the second Montana exception because the health and welfare of the tribe were at stake. Note that meeting the requirements of the second Montana exception only takes care of the subject matter jurisdiction question. The tribal court would still have to acquire personal jurisdiction over the defendant in order to properly adjudicate the case.

Furthermore, these relatively restrictive limitations on jurisdiction have been imposed by the Supreme Court and not by Congress, the latter of which has the plenary power to regulate Indian affairs under the Indian Commerce Clause. ${ }^{54}$ As Judge Canby has noted, "The civil jurisdiction of tribal courts . . . is subject to no statutory limit on the relief the courts may grant.. ${ }^{55}$ Thus, it is at least theoretically possible that Congress may step in and reassert itself in this area. ${ }^{56}$ If Congress were to clarify that tribal courts are courts of general jurisdiction, even

no power to legislate the tort law governing the action, it certainly would have diversity jurisdiction to adjudicate the claim. See 28 U.S.C. $\$ 1332$ (2000). Similarly, a state does not have the power to legislate in an area reserved exclusively to the federal government. However, absent a federal statute to the contrary, a state court would still have jurisdiction to hear the federal claim in that area. See supra note 30.

${ }^{50} 450$ U.S. $544,565-67$ (1981).

51520 U.S. 438, 453 (1997). While Strate itself did not cover tribal-owned land, Hicks extended the holding in Strate to do so. Hicks, 533 U.S. at 359-60.

${ }^{52}$ Hicks, 533 U.S. at 402 (Stevens, J., dissenting).

Id. at $367 \mathrm{n} .8$ (majority opinion).

${ }^{54}$ See infra notes 157-62 and accompanying text (arguing that if a branch of the federal government is to have the power to regulate tribal courts, it should be Congress).

${ }^{55}$ CANBY, supra note 12, at 187 (emphasis added).

${ }^{56}$ This Comment takes no position as to the likelihood of congressional action. 
if it were to place limits on their subject matter jurisdiction, ${ }^{57}$ then the proper exercise of personal jurisdiction by tribal courts would become even more important.

That being said, as the law currently stands, the tribal court's subject matter jurisdiction is limited by Montana, Strate, and Hicks. The Supreme Court has not yet explicitly decided how the personal jurisdiction of the tribal courts should be limited. The remainder of this Comment deals with that question, arguing that the Due Process Clause of the ICRA, which has at least a surface similarity to the Fifth and Fourteenth Amendments, limits the exercise of personal jurisdiction over nonconsenting defendants by tribal courts.

\section{INTERPRETING THE ICRA}

On June 22, 1965, Senator Sam Ervin, then chairman of the Subcommittee on Constitutional Rights of the Senate Judiciary Committee, held hearings on proposed legislation to grant constitutional rights to Indians with respect to tribal governments. ${ }^{58}$ The proposed legislation's first section provided " $[\mathrm{t}]$ hat any Indian tribe in exercising its powers of local self-government shall be subject to the same limitations and restraints as those which are imposed on the Government of the United States by the United States Constitution." ${ }^{\text {59 }}$ After significant criticism and calls for revision, ${ }^{60}$ the final act instead enumerated about twenty rights. ${ }^{61}$

${ }^{57}$ Simply limiting some of the tribal courts' subject matter jurisdiction in specific areas would not turn them into courts of limited jurisdiction, any more than giving federal courts exclusive jurisdiction over a subset of cases, see, e.g., 28 U.S.C. $§ 1333$ (admiralty); $i d . \S 1338$ (a) (patents), means that state courts do not have general jurisdiction. The broader point is that tribal courts should be presumed to have jurisdiction unless explicitly limited by Congress or tribal law.

${ }^{58}$ Such legislation was necessary because tribal governments are not bound by the Bill of Rights. See Talton v. Mayes, 163 U.S. 376, 384 (1896) ("It follows that as the powers of local self government enjoyed by the Cherokee nation existed prior to the Constitution, they are not operated upon by the Fifth Amendment, which, as we have said, had for its sole object to control the powers conferred by the Constitution on the National Government.").

${ }^{59}$ See Constitutional Rights of the American Indian: Hearings on S. 961-968 and S.J. Res. 40 Before the Subcomm. on Constitutional Rights of the S. Comm. on the Judiciary, 89th Cong. 5 (1965) [hereinafter 1965 Hearings] (excerpt from the Congressional Record, Feb. 2, $1965)$.

${ }^{60}$ See infra Part II.B (detailing the Act's legislative history).

${ }^{61}$ See ICRA, Pub. L. No. 90-284, § 202, 82 Stat. 73, 77-78 (1968) (codified at 25 U.S.C. $\$ 1302$ (2000)) (enumerating actions that “[n]o Indian tribe in exercising powers of self-government shall" do). 
Specifically, the ICRA provides, "No Indian tribe in exercising powers of self-government shall . . . deprive any person of liberty or property without due process of law." ${ }^{~} 22$ This language almost directly tracks that of the Fourteenth Amendment, which states that no state shall "deprive any person of life, liberty, or property, without due process of law." With the exception of the exclusion of the word "life"-unsurprising perhaps because Indian tribes are prohibited from administering the death penalty ${ }^{64}$-these provisions have exactly the same language. Because determining what process is due is not further elaborated by the text of the ICRA, congruence to the Fourteenth Amendment may not necessarily be required. However, both the canons of statutory construction and the legislative history of the Act require that the ICRA be interpreted similarly to the Fourteenth Amendment. ${ }^{65}$

\section{A. Canons of Statutory Construction}

Staying within the four corners of the text of the ICRA itself and interpreting it using a reasonable subset of the canons of construction require that the Due Process Clauses of the ICRA and Fourteenth Amendment be read similarly. Professor Eskridge defines the "canons of statutory construction" as "a homely collection of rules, principles, and presumptions" that "have served as a collective security blanket for lawyers and judges because they combine predictability and legitimacy in statutory interpretation ...."66 Eskridge separates the canons into three groups: (1) textual canons, which relate to how the text itself is read; (2) extrinsic source canons, which determine how much deference to accord previous interpretations of the same statutory language; and (3) substantive canons, which give background legal and policy principles to statutory construction. ${ }^{67}$

The textual canons support reading the ICRA analogously to the Fourteenth Amendment of the Constitution. One rule requires "[f] ollow[ing] ordinary usage of terms unless Congress gives them a

${ }^{62} 25$ U.S.C. $\$ 1302(8)$.

${ }^{63}$ U.S. CONST. amend. XIV, $§ 1$.

${ }^{64}$ See 25 U.S.C. $\$ 1302(7)$ (limiting tribal courts' sentencing power to fines or imprisonment lasting no more than six months).

${ }^{65}$ Such interpretation should continue to track the development of the courts' Fourteenth Amendment jurisprudence.

${ }^{66}$ William N. Eskridge, JR., Dynamic Statutory Interpretation 275 (1994) [hereinafter ESKRIDGE, DYNAMIC].

${ }^{67} I d$. at 323 app. 3. 
specified or technical meaning." ${ }^{68}$ The term "due process of law" has an ordinary legal usage, even if the meaning of the term has been reinterpreted over the years. ${ }^{69}$ There is no indication that some other usage for the same term was intended by Congress. Furthermore, "[e]ach statutory provision should be read by reference to the whole act." ${ }^{, 70}$ The entire act, especially the whole of section 1302, lists a large number of common procedural rights found elsewhere in the Constitution, which indicates a desire to incorporate the structure and language of the Bill of Rights and the Fourteenth Amendment into the ICRA.

The extrinsic source canons are perhaps the best support for construing the ICRA similarly to the Bill of Rights and the Fourteenth Amendment. In Lorillard v. Pons, the Supreme Court held that "where, as here, Congress adopts a new law incorporating sections of a prior law, Congress normally can be presumed to have had knowledge of the interpretation given to the incorporated law, at least insofar as it affects the new statute." ${ }^{71}$ Quoting this statement, Professor Eskridge has characterized it as "a leading statement of both the reenactment and the borrowed statute rules," ${ }^{72}$ the latter of which is relevant here. In another work, he defined the borrowed statute rule as follows: "[W]hen Congress borrows a statute, it adopts by implication interpretations placed on that statute, absent express statement to the contrary." ${ }^{73}$ The text of the statute itself indicates that Congress borrowed the statutory language. ${ }^{74}$ Based on the text and the borrowed statute canon, Congress can reasonably be assumed to have intended that previous interpretations of the Due Process Clause apply to the

${ }^{68}$ Id.; see also, e.g., Will v. Mich. Dep't of State Police, 491 U.S. 58, 64 (1989) (holding that a "state" is not a "person" in the context of 42 U.S.C. $§ 1983$ because the term "person" ordinarily does not cover a state).

${ }^{69}$ See BLACK’s LAW Dictionary 516 (7th ed. 1999) (defining the basic principle of due process).

${ }^{70}$ ESkRIDGe, DyNAMIC, supra note 66 , at 324 app. 3 (citing Pavelic \& LeFlore v. Marvel Entm't Group, 493 U.S. 120, 123-24 (1989); Massachusetts v. Morash, 490 U.S. 107 (1989)).

${ }^{71} 434$ U.S. 575, 581 (1978).

${ }^{72}$ WiLLIAM N. ESKRIDGE, JR. ET AL., LEGISLATION AND STATUTORY INTERPRETATION 283 n.87 (2000) [hereinafter ESKRIDGE, LEGISLATION].

${ }^{73}$ ESKRIDGE, DYNAMIC, supra note 66, at 324 app. 3. Interestingly, in ESKRIDGE, LEgISLATION, supra note 72, at 287-328, Professor Eskridge does not include this canon in his extrinsic sources chapter, but he does include it as an extrinsic source canon in ESKRIDGE, DYNAMIC, supra note 66, at 324 app. 3.

${ }^{74}$ The legislative history should hopefully settle any doubt that the drafters of the ICRA intended to borrow the language. See infra Part II.B. 
ICRA as well. ${ }^{75}$ These interpretations included the substantive limitations on personal jurisdiction that the Court had read into the Fourteenth Amendment starting nearly a century before the passage of the ICRA. $^{76}$

Finally, the substantive policy canons support limiting tribal personal jurisdiction by interpreting the ICRA as parallel to the Fourteenth Amendment. Professor Eskridge notes that "a longstanding interpretive principle is that ambiguities in federal Indian treaties and statutes involving Indian affairs will be construed in favor of Native Americans." ${ }^{, 7}$ Although interpreting the ICRA similarly to the Fourteenth Amendment limits tribal power to adjudicate disputes, bringing tribal courts into the mainstream of American jurisprudence, especially in an area like personal jurisdiction that concerns the fairness of subjecting a defendant to a forum, could actually benefit tribes by increasing trust in tribal court systems. ${ }^{78}$ Thus, the ICRA should be interpreted, based on reasonable and largely noncontroversial canons of construction, as containing the same protections as the Fourteenth Amendment.

\section{B. The Legislative History}

One of the most important and controversial extrinsic source canons is the "[c]onsider[ation of] legislative history when [the] stat-

${ }^{75}$ For an argument that Congress can have collective intentions, see generally Abby Wright, Comment, For All Intents and Purposes: What Collective Intention Tells Us About Congress, 154 U. PA. L. REV. 983 (2006).

${ }^{76}$ See Pennoyer v. Neff, 95 U.S. 714, 714-15 (1877) (constitutionalizing territorial jurisdiction). Of course, personal jurisdiction has evolved since then, but even the seminal case for modern personal jurisdiction, International Shoe Co. v. Washington, 326 U.S. 310 (1945), was over twenty years old when the ICRA was enacted.

${ }^{77}$ ESKRIDGE, LEGISLATION, supra note 72, at 340.

${ }^{78}$ Indeed, as Professor Gould has noted,

The root cause of the Court's unwillingness to vest tribes with regulatory or adjudicatory jurisdiction over non-Indians and nonmembers is its inability to reconcile the constitutional protection of individual rights with the tribal conception of group rights.... [T] he rights of individuals to due process and equal protection are hallmarks of the Constitution and the Court's modern jurisprudence.

L. Scott Gould, Tough Love for Tribes: Rethinking Sovereignty after Atkinson and Hicks, 37 NEW ENG. L. REV. 669, 674 (2003). Note especially that Professor Gould focuses on the Supreme Court's actions. However, Congress enacted the ICRA to remedy exactly this problem, see infra Part II.B, and it is Congress-not the Supreme Court-that has plenary power over the tribes. See infra notes 157-62 and accompanying text (noting that the Indian Commerce Clause has been interpreted to give Congress plenary power over Indians). 
ute is ambiguous." ${ }^{, 9}$ Courts often refuse to "search legislative history for congressional intent unless they find the statute unclear or ambiguous." ${ }^{80}$ Some jurists, most notably Justice Antonin Scalia, "object to the use of legislative history on principle." ${ }^{\prime 1}$ On the other hand, Justice Stephen Breyer has defended the practice. ${ }^{82}$ Thus, if this question were to reach the Supreme Court, the weight accorded legislative history would depend on the Justice writing the opinion. In any case, examining the legislative history only further strengthens the argument that the ICRA should be interpreted similarly to the Fourteenth Amendment.

In 1961, Senator Ervin held his first hearings on the Constitutional Rights of the American Indian, which he considered an "all too long neglected area of the law." ${ }^{\prime 3}$ Senator Ervin was concerned that Indians were a large group of American citizens who paradoxically had full constitutional rights off the reservation, but had only limited constitutional rights on the reservation. ${ }^{84}$ During the first set of hearings, which lasted for about eighteen months, the concern that tribal governments were not giving their citizens full civil rights, especially in their court systems, was echoed by Senators Hruska, ${ }^{85}$ Church, ${ }^{86}$ Burdick, ${ }^{87}$ Case, ${ }^{88}$ Carroll, ${ }^{89}$ and Keating (who specifically mentioned due process)..$^{90}$ On one of the last days of the hearings, Senator Ervin worried that "there is serious question of deprivation of the right to due process as guaranteed under the 5th and 14th Amendments."

${ }^{79}$ ESKRIDGE, DYNAMIC, supra note 66, at 325.

${ }^{80}$ In re Abbott Labs., 51 F.3d 524, 528 (5th Cir. 1995); see also Exxon Mobil Corp. v. Allapattah, 125 S. Ct. 2611, 2625 (2005) (rejecting "at the very outset" an argument that the legislative history of a statute should be used to interpret it "because [the statute] is not ambiguous").

${ }^{81}$ ANTONIN SCALIA, Common-Law Courts in a Civil-Law System, in A MATTER OF INTERPRETATION 3, 31 (Amy Gutmann ed., 1997).

${ }^{82}$ See, e.g., Stephen Breyer, On the Uses of Legislative History in Interpreting Statutes, 65 S. CAL. L. REV. 845 (1992) (defending the "classical practice" of consulting legislative history).

83 Constitutional Rights of the American Indian: Hearings Pursuant to S. Res. 53 Before the Subcomm. on Constitutional Rights of the S. Comm. on the Judiciary, 87th Cong., pt. 1, at 1 (1961) (introduction).

84 Id. at 3 .

85 Id. at 6.

${ }^{86}$ Id. at 9 .

${ }^{87}$ Id. at 88

${ }^{88} I d$. at 132.

${ }^{89} I d$. at 286

${ }^{90}$ Id. at 357 .

${ }^{91} I d$. at 815 . 
In 1964, the subcommittee issued its first report on the subject, which Senator Ervin introduced by lauding the successful eighteenmonth hearings that were held in Washington, D.C., and nine different states; the hearings included testimony from representatives of more than fifty tribes. ${ }^{92}$ The report severely criticized tribal governments for their "failure to conform to traditional constitutional safeguards which apply to State and Federal action." made twelve recommendations, first and foremost that the "constitutional rights and protections conferred upon American citizens should be made applicable to American Indians in their relationship with their tribal governing bodies." ${ }^{\text {94 }}$ The language of this report evinced a fairly clear intent on the part of the drafters of the ICRA, even as early as 1964, to apply the constitutional norms applicable to state and federal governments, including due process, to Indian tribes.

The hearings continued in 1965, soon after Senator Ervin's initial introduction of the ICRA to the eighty-ninth Congress. ${ }^{95}$ These hearings continued in the same vein, focusing on Senator Ervin's proposed legislation. The first bill provided that the guarantees required of tribal governments should be exactly the same as those required of the federal government under the United States Constitution. ${ }^{96}$ However, the Solicitor of the Department of the Interior voiced concerns that the Constitution as a whole was grounded in Western legal philosophy not necessarily shared by Indians. ${ }^{97}$ He objected to the legislation as too general, and instead offered "substitute legislation which specifie[d] the rights extended to individual Indians in relation to their tribal governments, "in which he included due process ${ }^{98}$ it is unclear, however, whether he meant the same due process rights as required by the United States Constitution. At the same time, senators

\footnotetext{
${ }^{92}$ STAFF OF THE SubCOMm. ON CONSTITUTIONAL Rights OF THE S. COMM. ON THE JUDICIARY, 88TH CONG., REPORT ON CONSTITUTIONAL RigHTS OF THE AMERICAN INDIAN, at v (Comm. Print 1964).

${ }_{93} I d$. at 4 .

${ }^{94} I d$. at 23. The sixth recommendation, arguably more significant but beyond the scope of this Comment, called for retrocession of state jurisdiction back to the federal government under Public Law 280. Id.; see also CANBY, supra note 12, at 239-42 (describing the process of retrocession and its effects on Indian law).

951965 Hearings, supra note 59, at 1.

${ }^{96} I d$. at 5 .

${ }^{97}$ Id. at 17 (statement of Frank J. Barry, Solicitor, Department of the Interior).

${ }^{98}$ Id. at $17-18$.
} 
continued to voice their concern about Indians occupying "a no man's land with regard to their constitutional rights." ${ }^{99}$

In 1966, the subcommittee issued yet another report, concluding again that the "deprivation of individual rights by tribal governments" was a serious problem on Indian reservations. ${ }^{100}$ However, the report also recommended that, as the Department of the Interior had suggested, the rights of Indians should be enumerated in the bill rather than incorporated wholesale from the Constitution. ${ }^{101}$ The bill went nowhere during the eighty-ninth Congress, but Senator Ervin pushed it in the next Congress, and the full committee issued an official report with the proposed legislation that would become the ICRA. ${ }^{102}$ The report explained that "[t]hese limitations are the same as those imposed on the Government of the United States by the U.S. Constitution and on the States by judicial interpretation."103 Four months later, after nearly seven years in the making, the ICRA was enacted by Congress. ${ }^{104}$

The drafters of the ICRA were deeply concerned by the lack of civil rights on Indian reservations and wanted to bring American constitutional norms to the tribal governments. One of these norms is the concept of procedural due process, including the modern conception of personal jurisdiction that had existed for over two decades prior to the passage of the ICRA.

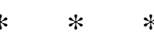

Contending that the ICRA should be interpreted this way is not uncontroversial. $^{105}$ For instance, one academic commentator has sug-

99 Id. at 61 (statement of Sen. Hiram L. Fong of Hawaii).

100 STAFF OF THE SUbCOMM. ON CONSTITUTIONAL RigHtS OF THE S. COMM. ON THE JUDICIARY, 89TH CONG., REPORT ON CONSTITUTIONAL RIGHTS OF THE AMERICAN INDIAN (Comm. Print 1966).

101 Id. at 25.

102 S. REP. NO. 90-841, at 1-5 (1967).

103 Id. at 6 (emphasis added).

104 ICRA, Pub. L. No. 90-284, § 202, 82 Stat. 73, 77-78 (1968).

105 See, e.g., Estate of Tasunke Witko v. G. Heileman Brewing Co., 23 Indian L. Rep. 6104, 6108 (Rosebud Sioux Sup. Ct. 1996) (suggesting that parallel language did not require parallel interpretations (citing Tom v. Sutton, 533 F.2d 1101, 1104 n.5 (9th Cir. 1976) and Wounded Head v. Tribal Council of Oglala Sioux Tribe, 507 F.2d 1079, 1082-83 (8th Cir. 1975))); Note, The Indian Bill of Rights and the Constitutional Status of Tribal Governments, 82 HARV. L. REV. 1343, 1354 (1969) (suggesting that despite the "verbatim copying of constitutional language... strengthened by statements in the legislative history to the effect that tribal governments were to respect the 'same consti- 
gested that interpreting the Due Process Clause of the ICRA should vary with tribal values. ${ }^{106}$ While it is hard to argue with respecting "tribal values" in the abstract, it is important to note that Congress passed the ICRA because it was concerned that "tribal values" were being used to justify depriving a subset of American citizens of their constitutional rights. Furthermore, there is nothing that prohibits a tribe from applying its own values to the extent it allows personal jurisdiction, so long as the exercise of such jurisdiction does not also violate the federal due process guarantee embodied in the ICRA.

Congress, in enacting the ICRA, placed on the tribal governments substantive limits based on Western values, not tribal ones. However, at least in terms of personal jurisdiction, concerns about the propriety and wisdom of such action may be more worrisome to the academy than to those in the field. Indeed, somewhat ironically, some tribal courts, when analyzing limits on their own personal jurisdiction, have been more willing to apply Supreme Court personal jurisdiction jurisprudence than have been the federal courts that reviewed those tribal court decisions and found it not applicable.

\section{LIMITS ON PERSONAL JURISDICTION}

A court's acquisition of jurisdiction over a particular defendant is limited by both the internal law of the jurisdiction ${ }^{107}$ and the external due process requirements. ${ }^{108}$ Both the federal Constitution and the

tutional rights' as state and federal governments," such an interpretation would impinge a policy that was not explicitly overturned).

106 See Donald L. Burnett, Jr., An Historical Analysis of the 1968 'Indian Civil Rights' Act, 9 HARV. J. ON LEGIS. 557, 617 (1972) (arguing that federal courts should not apply expanding notions of due process and equal protection to cases arising under the ICRA, which should be interpreted with sensitivity to tribal values).

${ }^{107}$ See, e.g., NAVAJO NATION CODE tit. 7, § 253 (1995) ("The District Courts of the Navajo Nation shall have original jurisdiction over... [a]ll civil actions in which the defendant is a resident of Navajo Indian Country, or has caused an action to occur within the territorial jurisdiction of the Navajo Nation."); $i d . \$ 254$ ("The territorial jurisdiction of the Navajo Nation shall extend to Navajo Indian Country ....").

108 See FRIEDENTHAL ET AL., supra note 28, § 3.1 ("A state cannot exercise its adjudicatory authority over a party or a piece of property unless it has both the statutory authority and the constitutionally recognized power to do so."). The Supreme Court highlighted this difference in Helicopteros Nacionales de Colombia v. Hall, holding "that Helicol's contacts with the State of Texas were insufficient to satisfy the requirements of the Due Process Clause of the Fourteenth Amendment." 466 U.S. 408, 418-19 (1984). However, the Court also noted that it was "not within [its] province" to determine whether personal jurisdiction was valid under Texas law and simply presumed the limits under state law to be "coextensive with those of the Due Process Clause," which is effectively what the Texas Supreme Court had held below. Id. at 413 \& n.7. 
ICRA limit jurisdiction through due process requirements. ${ }^{109}$ Some tribal courts ${ }^{110}$ have shown a strong willingness to rely upon the United States Supreme Court's minimum contacts jurisprudence, ${ }^{111}$ when deciding the external limitations placed on their personal jurisdiction. ${ }^{112}$

For instance, in Rosebud Housing Authority v. LaCreek Electric Cooperative, Inc., the Rosebud Sioux Tribal Court held that International Shoe was dispositive in determining personal jurisdiction, and that "[t] he defendant has had [enough] minimum contacts on the reservation to constitute a 'presence' so that assertion of personal jurisdiction over it by this court will not violate due process . ..."113 Ten years later, the Coeur d'Alene Tribal Court engaged in a much more extensive analysis to determine if it had specific jurisdiction over AT\&T. ${ }^{114}$ The court analyzed in detail whether the facts before it constituted purposeful availment, forum-related activities, and fair play and substantial justice, and found that it had jurisdiction over AT\&T. ${ }^{115}$ In both cases, the courts looked to federal case law to determine the extent of jurisdiction available under due process of law, although neither specifically mentioned the ICRA.

Personal jurisdiction was at issue in two other tribal matters that gained national significance: the litigation surrounding Crazy Horse Malt Liquor, which created a large enough public relations contro-

109 See supra Part II.

110 This is by no means a comprehensive survey, but rather a look at a handful of interesting tribal court decisions. For other commentary discussing how tribal courts have applied personal jurisdiction, see, for example, Newton, supra note 3, at 322-26 (explaining how various tribal courts have interpreted personal jurisdiction); Sarah Krakoff, A Narrative of Sovereignty: Illuminating the Paradox of the Domestic Dependent $\mathrm{Na}$ tion, 83 OR. L. REV. 1109, 1137-38 (2004) (discussing the Navajo court system and noting that "principles from federal law, such as the interpretation of due process in the context of personal jurisdiction, have been adopted by the tribal courts").

${ }^{111}$ This jurisprudence stems from International Shoe Co. v. Washington, 326 U.S. 310 (1945).

${ }^{112}$ I will focus more on the external limitations, such as the ICRA, because the handful of tribal statutes that I have encountered authorize personal jurisdiction to the full extent allowed by the Due Process Clause. See, e.g., Coeur D'Alene Tribe v. AT\&T Corp., 23 Indian L. Rep. 6060, 6063 (Coeur D'Alene Tribal Ct. 1996) (citing the tribe's long-arm statute, which requires minimal contact to assert extraterritorial jurisdiction over a party); infra note 125 and accompanying text (citing the Rosebud Sioux Tribe's long-arm statute, which provides jurisdiction " $[\mathrm{t}] \mathrm{o}$ the greatest extent consistent with due process of law").

11313 Indian L. Rep. 6030, 6031-32 (Rosebud Sioux Tribal Ct. 1986).

114 ATE्TT, 23 Indian L. Rep. at 6063-64.

115 Id. 
versy to cause Congress to intervene, and an auto accident, which was the seed for a major Supreme Court case that drastically undermined the scope of tribal court jurisdiction. In the end, however, the federal courts disposed of the cases on subject matter, and not personal, jurisdiction grounds. This Part analyzes each of these matters and discusses the limits that federal courts may attempt to place on the exercise of personal jurisdiction by tribal courts.

\section{A. The Original Crazy Horse Malt Liquor}

In perhaps one of the most questionable marketing ideas ever, Hornell Brewing Company introduced "The Original Crazy Horse Malt Liquor" in March 1992. ${ }^{116}$ The name received significant negative publicity, condemned by, among others, tribal leaders and Surgeon General Antonia Novello. ${ }^{117}$ Not long after, Congress stepped in and specifically forbade the Bureau of Alcohol, Tobacco, and Firearms from issuing a license to any liquor company wishing to use the name Crazy Horse, ${ }^{118}$ although that act was later held to be unconstitutional by a district court. ${ }^{119}$

Understandably upset, an heir to Tasunke Witko (Crazy Horse's Sioux name $)^{120}$ brought suit on behalf of the estate in tribal court under the Lanham Act ${ }^{121}$ and the Indian Arts and Crafts Act. ${ }^{122}$ The tribal trial court dismissed the case for want of jurisdiction, but "did not appear to distinguish between personal and subject matter juris-

${ }^{116}$ Estate of Tasunke Witko v. G. Heileman Brewing Co., 23 Indian L. Rep. 6104, 6105 (Rosebud Sioux Sup. Ct. 1996). Crazy Horse was a Sioux military leader who triumphed over the United States Seventh Cavalry at Little Big Horn in 1876, the battle in which General Custer was killed. One modern Sioux biographer characterized him as "a genuine hero to Lakota [Sioux] people." JOSEPH M. MARSHALL III, THE JOURNEY OF CRAZY HORSE, at xix (2004). For additional biographies of Crazy Horse, see Stephen Ambrose, Crazy Horse and Custer (1975) and Mike Sanja, Crazy Horse: THE LIFE BEHIND THE LEGEND (2000).

117 See, e.g., Editorial, Again, Misreading the Sioux, Boston Globe, May 20, 1992, at 16 (detailing some of the complaints and strongly condemning the company's actions).

118 Treasury, Postal Service, and General Government Appropriations Act, Pub. L. No. 102-393, § 633, 106 Stat. 1729, 1777 (1992).

119 See Hornell Brewing Co. v. Brady, 819 F. Supp. 1227, 1228 (E.D.N.Y. 1993) (holding that the First Amendment prohibits enforcement of the ban on naming alcoholic beverages after Crazy Horse).

${ }^{120}$ Estate of Tasunke Witko, 23 Indian L. Rep. at 6105.

121 15 U.S.C. $\$ 1125$ (a) (2000).

122 25 U.S.C. $\$ 305 \mathrm{e}(2000)$. 
diction." ${ }^{123}$ The estate appealed to the Rosebud Sioux Supreme Court, which found that the issue of personal jurisdiction "appear[ed] to be at the heart of the trial court's decision." ${ }^{124}$ The Rosebud Sioux Supreme Court first looked to the internal tribal limitation on its jurisdiction, Rosebud Sioux Tribe Law and Order Code section 4-2-7, which provides for personal jurisdiction over those who commit tortious acts " $[\mathrm{t}] \mathrm{o}$ the greatest extent consistent with due process of law." ${ }^{125}$ Like many state analyses, ${ }^{126}$ this provision effectively collapses the two questions of personal jurisdiction-whether both internal and external limitations are met-into the unitary inquiry of whether due process is met.

At this point, the tribal court might have engaged in its own independent analysis of what process is due, regardless of the ICRA, under the theory that federal law is not binding on the tribal courts. ${ }^{127}$ However, the tribal court read the U.S. Supreme Court's opinion in $\mathrm{Na}$ tional Farmers Union Insurance Cos. v. Crow Tribe ${ }^{128}$ broadly for the proposition that "the proper extent of tribal court jurisdiction is ultimately a matter of federal (common) law and therefore as to matters of jurisdiction, federal standards-including 'minimum contacts' due process analysis-are applicable." ${ }^{29}$ A narrower reading of National Farmers might limit its holding to subject matter jurisdiction only ${ }^{130}$ and find that the case simply does not speak to the personal jurisdiction issue. Furthermore, the tribal court could have refused to read into National Farmers the requirement that a tribal court use federal standards to determine its own jurisdiction ${ }^{131}$ even if those federal

${ }^{123}$ Estate of Tasunke Witko, 23 Indian L. Rep. at 6106.

${ }^{124} \mathrm{Id}$. at 6107.

${ }^{125} I d$. at 6107 n.21 (quoting Rosebud Sioux Tribe Law and Order Code $§ 4-2-7$ (1989)).

${ }^{126}$ See, e.g., supra note 108 (noting that the Texas long-arm statute goes as far as due process would allow).

${ }^{127}$ See, e.g., Clinton, supra note 48, at 116 ("Consequently, neither Congress nor the federal courts legitimately can unilaterally adopt binding legal principles for the tribes without their consent.").

128471 U.S. 845 (1985).

${ }^{129}$ Estate of Tasunke Witko, 23 Indian L. Rep. at 6108.

${ }^{130}$ See 471 U.S. at 855 (answering "the question whether a tribal court has the power to exercise civil subject-matter jurisdiction over non-Indians").

${ }^{131}$ Given the general hostility of non-Indians toward tribal courts, it is only prudent for a tribal court to not ignore, and indeed to adopt, federal law. See Newton, su pra note 3, at 294 ("[W] hen non-Indian parties are involved, tribal judges adjudicate with a kind of Sword of Damocles over their heads.”). 
standards were different than tribal conceptions of due process. However, the tribal court did not go down either route.

Instead, the court applied a minimum contacts analysis based on federal territorial jurisdiction precedent. ${ }^{132}$ The court found purposeful availment in the advertising and sale of other products and specifically noted that the harm caused was not caused because the product was defective. Rather, the harm occurred in the forum because the use of the "Crazy Horse" name harmed the publicity rights of the plaintiff, who was domiciled on the reservation. ${ }^{133}$

The tribal court further held that Montana $v$. United States ${ }^{134}$ did not apply since it concerned regulatory, not adjudicatory, jurisdiction. Recall that Montana held that there were two exceptions to the general rule depriving tribes of regulatory jurisdiction over nonIndians: ${ }^{135}$ regulating nonmembers who enter into consensual relationships with the tribe, ${ }^{136}$ and regulating activity directly affecting the general welfare of the tribe. ${ }^{137}$ The tribal court further held that even if Montana did apply, the second exception would apply because the tribe has an interest in providing a forum for its members, especially in the context of misappropriation of a venerated tribal hero. ${ }^{138}$ The court also criticized and refused to follow a then-recent Eighth Circuit

${ }^{132}$ Estate of Tasunke Witko, 23 Indian L. Rep. at 6108-10 (citing Helicopteros Nacionales de Colombia v. Hall, 466 U.S. 408, 413 n.7 (1984); Calder v. Jones, 465 U.S. 783 (1984); Burger King v. Rudzewicz, 471 U.S. 462 (1985); Shaffer v. Heitner, 433 U.S. 186 (1977); as well as a number of United States courts of appeals cases).

${ }^{133}$ Id. at 6010 .

134450 U.S. 544 (1981).

135 The distinction between nonmember and non-Indian was not found to be important by the Supreme Court in Duro v. Reina, 495 U.S. 676, 684-88 (1990), which extended the prohibition against tribes criminally punishing non-Indians, see Oliphant v. Suquamish Indian Tribe, 435 U.S. 191, 212 (1978) ("Indian tribes do not have inherent jurisdiction to try and to punish non-Indians."), to also prohibit tribes from punishing nonmembers. This controversial distinction was "fixed" by Congress soon thereafter, and it remains to be seen whether civil jurisdiction will turn on such a distinction. See 25 U.S.C. $\$ 1301(2)$ (2000) (granting tribes power to "exercise criminal jurisdiction over all Indians"); Catherine T. Struve, Tribal Immunity and Tribal Courts, 36 ARIZ. ST. L.J. 137, 147 n.63 (referring to the "Duro fix").

${ }^{136}$ Montana, 450 U.S. at 565 ("A tribe may regulate, through taxation, licensing, or other means, the activities of nonmembers who enter consensual relationships with the tribe or its members, through commercial dealing, contracts, leases, or other arrangements.").

${ }^{137} I d$. at 566 ("A tribe may also retain inherent power to exercise civil authority over the conduct of non-Indians on fee lands within its reservation when that conduct threatens or has some direct effect on the political integrity, the economic security, or the health or welfare of the tribe.").

${ }^{138}$ Estate of Tasunke Witko, 23 Indian L. Rep. at 6111-12. 
en banc opinion that expanded Montana to include civil adjudication. ${ }^{139}$

Hornell brought its case to federal court, and the case eventually made its way to the Eighth Circuit. ${ }^{140}$ Hornell challenged the tribal court's additional holding that it had subject matter jurisdiction over the action. Relying in part on Strate $v$. A-1 Contractors, ${ }^{141}$ the Eighth Circuit held that the sale of other beverages was insufficient to confer subject matter jurisdiction under the first Montana exception because the sale of the offending product did not occur on the reservation itself. $^{142}$ Additionally, it found the tribe's interest in providing tribal members a forum to litigate insufficient to satisfy the second Montana exception, which the tribe argued would have allowed jurisdiction due to the suit's substantial effect on the health and welfare of the tribe. ${ }^{143}$ By restricting the case to a review of subject matter jurisdiction only,

${ }^{139}$ Id. at 6112-13 (citing A-1 Contractors v. Strate, 76 F.3d 930 (8th Cir. 1996) (en banc)); see also infra Part III.B (discussing the Eighth Circuit case that expanded Montana).

${ }^{140}$ Hornell Brewing Co. v. Rosebud Sioux Tribal Court, 133 F.3d 1087 (8th Cir. 1998). Hornell had requested that the federal court enjoin the tribal court from exercising jurisdiction over the matter. See Nat'l Farmers Union Ins. Cos. v. Crow Tribe, 471 U.S. 845, 850-53 (1985) (creating a cause of action to challenge tribal jurisdiction in federal court); see also infra Part IV.A (discussing the applicability of National Farmers to personal jurisdiction challenges).

${ }^{141} 520$ U.S. 438 (1997).

${ }^{142}$ Hornell, 133 F.3d at 1093.

${ }^{143} I d$. The Eighth Circuit's reasoning was flawed for two reasons. First, it gave absolutely no weight to the tribal court decision, even though one of the main justifications for tribal exhaustion given by the Supreme Court in National Farmers was to "encourage tribal courts ... [to] provide other courts with the benefit of their expertise in [jurisdictional] matters in the event of further judicial review." Nat'l Farmers, 471 U.S. at 857. Second, the Eighth Circuit accorded no weight at all to the context in which these allegations arose, specifically the denigration of a "beloved Lakota leader known for his stance against alcohol.” Christopher J. Schneider, Note, Hornell Brewing Co. v. Rosebud Sioux Tribal Court: Denigrating the Spirit of Crazy Horse To Restrain the Scope of Tribal Court Jurisdiction, 43 S.D. L. REV. 486, 522 (1998). While perhaps not fitting neatly into Western conceptions of health and welfare, the tribal court specifically noted that the controversy over Crazy Horse Liquor was "[a] dispute of wideranging individual and collective tribal import.” Estate of Tasunke Witko, 23 Indian L. Rep. at 6112 (emphasis added).

In any case, the significance to the tribe should have been clear from the passage of Public Law 102-393, which forbade the Bureau of Alcohol, Tobacco, and Firearms from issuing a license for any liquor company's use of the name Crazy Horse, alone. See supra note 118 and accompanying text (discussing Congress's condemnation of Hornell's conduct); see also Press Release on Crazy Horse Malt Liquor, http:// www.ableza.org/CHorse.html (last visited Mar. 21, 2006) (describing the struggle by the Lakota Sioux against Heileman and the use of Crazy Horse as an alcohol marketing tool). 
the Eighth Circuit managed to avoid the thorny issue of personal jurisdiction.

\section{B. Gisela Fredericks's Car Accident}

In 1990, Gisela Fredericks was driving on a road within the boundaries of the Fort Berthold Indian Reservation when her car collided with a gravel truck owned by A-1 Contractors. Although Mrs. Fredericks was not a member of the tribe, her deceased husband and five children were all members. Furthermore, she had lived on the reservation for more than forty years and was considered "a member of the Fort Berthold community." ${ }^{144}$ She brought a personal injury tort claim in tribal court, which sustained its jurisdiction to hear the claim. ${ }^{145}$ The Northern Plains Intertribal Court of Appeals held that the "tribal court is subject to the limitations of minimum contacts in taking jurisdiction." ${ }^{146}$ However, it went on to hold that since the accident occurred on the reservation, the existence of minimum contacts was not a concern. ${ }^{147}$ Although the court's analysis is somewhat lacking, as it should have held that A-1 Contractors's purposeful entry into the reservation was sufficient, ${ }^{148}$ the question was at least raised and the result correct.

A-1 Contractors subsequently brought suit in federal district court, which upheld both the subject matter and personal jurisdiction of the tribal court. ${ }^{149}$ The district court held that it had jurisdiction under 28 U.S.C. $\S 1331$ to "determine the extent of tribal court jurisdiction," and included personal jurisdiction in its analysis. In doing so, the court avoided any discussion of why it should also imply a cause of action to review personal jurisdiction, as opposed to just subject matter jurisdiction. However, the court may not have thought that much dis-

${ }^{144}$ Fredericks v. Cont'l W. Ins. Co., 20 Indian L. Rep. 6009, 6010 (N. Plains Intertribal Ct. App. 1992).

${ }^{145}$ A-1 Contractors v. Strate, 19 Indian L. Rep. 3163, 3163 (D.N.D. 1992). This district court case came after the Northern Plains Intertribal Court of Appeals case even though it appears in an earlier reporter.

${ }^{146}$ Fredericks, 20 Indian L. Rep. at 6011 (citing World-Wide Volkswagen Corp. v. Woodson, 444 U.S. 286 (1980) and Int'l Shoe Co. v. Washington, 326 U.S. 310 (1945)).

${ }^{147} I d$.

148 See, e.g., Hanson v. Denckla, 357 U.S. 235, 253 (1958) (holding that purposeful availment is needed); World-Wide Volkswagen, 444 U.S. at 298-99 (holding that a defendant does not purposefully avail itself of a foreign state when the defendant's customer is the one who transports the defendant's product to that state).

${ }^{149}$ Strate, 19 Indian L. Rep. at 3164-65.

${ }^{150} I d$. at 3163 . 
cussion was necessary, after holding that the tribal court had jurisdiction.

A-1 Contractors appealed to the Eighth Circuit, where it lost the panel decision but won on review en banc. ${ }^{151}$ The en banc panel applied the Montana exceptions to the prohibition of regulatory authority over non-Indians, and held that there was no adjudicatory jurisdiction over non-Indians, ${ }^{152}$ thus completely disposing of the case on subject matter jurisdiction grounds and not reaching the issue of personal jurisdiction. ${ }^{153}$ The Supreme Court, per Justice Ginsburg, unanimously affirmed the Eighth Circuit, holding that Montana applied to adjudicatory as well as regulatory jurisdiction. ${ }^{154}$ The Supreme Court also did not reach the personal jurisdiction issue. ${ }^{155}$

\section{Federal Court Power To Limit Personal Jurisdiction}

Although some tribal courts have found limits to their personal jurisdiction in the Due Process Clause of the ICRA and their own constitutions, as described in Part III.B, the federal courts have yet to define the scope of tribal personal jurisdiction. The Supreme Court's recent trend seems to be to use Montana for all tribal power; indeed, Justice Souter recently concurred solely to make this point: "If we are to see coherence in the various manifestations of the general law of tribal jurisdiction over non-Indians, the source of doctrine must be Montana v. United States...."156 However, if the ICRA governs tribal personal jurisdiction, as I have argued, coherence of doctrine is a weak justification for overstepping the proper role of the judiciary and intruding on the domain of Congress.

${ }^{151}$ A-1 Contractors v. Strate, 76 F.3d 930, 934 (8th Cir. 1996) (en banc) (8-4 decision).

${ }^{152} I d$. at 938.

${ }^{153}$ The dissenters did not reach the issue either. Id. at 941-51 (Beam, J., dissenting).

${ }^{154}$ Strate v. A-1 Contractors, 520 U.S. 438, 453 (1997).

${ }^{155}$ See Sarah Krakoff, Undoing Indian Law One Case at a Time: Judicial Minimalism and Tribal Sovereignty, 50 AM. U. L. REV. 1177, 1260 (2001) (arguing that the Supreme Court could have decided Strate on personal jurisdiction grounds, to wit, "whether a defendant has sufficient minimum contacts with a jurisdiction such that it comports with due process to subject him to suit there").

${ }^{156}$ Atkinson Trading Co. v. Shirley, 532 U.S. 645, 659 (2001) (Souter, J., concurring). 
Congress has the plenary power to govern Indian affairs. ${ }^{157}$ While the textual support in the Constitution for such a broad grant of authority is unclear, ${ }^{158}$ Dean Newton has argued that "plenary power" is "not so much [a] justification[] for decisional outcomes as [it is a] restatement[] of the Court's intent to defer to the other branches of government." ${ }^{159}$ If a branch of government is to have plenary power over Indian tribes (and with that the ability to regulate tribal court jurisdiction), it should be Congress, the elected political branch given responsibility for setting Indian policy in Article I, and not the judicial branch. Although tribal self-government is central to modern Indian policy, ${ }^{160}$ the Supreme Court, rather than supporting the congressional policy, instead has "continue[d] the jurisdictional assault on tribalism and tribal sovereignty.",

There is simply no direct textual support in either constitutional or statutory law for the power the Court exerted in Montana. However, it can be argued that because Indian law is primarily the province of the federal government, the Court was exercising its specific federal common law powers in Montana. ${ }^{162}$ Of course, even if the Court has the power to create federal common law in this area, this does not mean that the result in Montana was correct. ${ }^{163}$ In any case,

${ }^{157}$ This power derives from the broadly interpreted Indian Commerce Clause. See U.S. Const. art. I, $\S 8$, cl. 3 (granting Congress the power to "regulate Commerce . . with the Indian tribes"); United States v. Lara, 541 U.S. 193, 200 (2004) ("The central function of the Indian Commerce Clause . . . is to provide Congress with plenary power to legislate in the field of Indian affairs." (citation omitted)).

${ }^{158}$ See Clinton, supra note 48, at 115 ("[T] here is no acceptable, historicallyderived, textual constitutional explanation for the exercise of any federal authority over Indian tribes without their consent manifested through treaty.").

${ }^{159}$ Nell Jessup Newton, Federal Power over Indians: Its Sources, Scope, and Limitations, 132 U. PA. L. REV. 195, 196 (1984).

${ }^{160}$ See generally Robert N. Clinton ET AL., AMERICAN INDIAN LAW: NATIVE NATIONS AND THE FEDERAL SYSTEM 41-48 (4th ed. 2003) (describing how modern congressional policy has focused on tribal self-governance).

${ }^{161}$ Clinton, supra note 48, at 213.

${ }^{162}$ See Lara, 541 U.S. at 207 (holding that Congress has the power to change judicially made Indian law and citing cases to support the notion that such law has a federal common law flavor); see also Clearfield Trust Co. v. United States, 318 U.S. 363, 367 (1943) ("In absence of an applicable Act of Congress it is for the federal courts to fashion the governing rule of law according to their own standards." (emphasis added)).

${ }^{163}$ See Philip P. Frickey, A Common Law for Our Age of Colonialism: The Judicial Divestiture of Indian Tribal Authority over Nonmembers, 109 YALE L.J. 1, 57 (1999) (arguing that Montana and its progeny are contrary to "the canons of interpretation that supposedly resolve open questions in favor of the tribes unless Congress has spoken clearly to the contrary"). 
because Congress passed the ICRA, which should govern the question of tribal court personal jurisdiction, there is simply no need to create federal common law. ${ }^{164}$

Thus, the two main limits on the exercise of personal jurisdiction by tribal courts are tribal law and the ICRA. The tribal courts surveyed have generally understood that due process limits their exercise of personal jurisdiction and have followed the federal standard. Furthermore, there is little reason that the standards should be different where the language of the textual provisions providing the law is so similar. Because Congress enacted the ICRA, the Supreme Court should exercise restraint and not impose any new restrictions on tribal personal jurisdiction. The Court, when the matter is properly before it, should hold the tribes to the same due process limitations under the ICRA to which it holds the states under the Fourteenth Amendment. In doing so, both tribal and federal courts can harmonize this area of law.

\section{SHOUld THE ICRA BE ENFORCED DiRECTLY BY FEDERAL COURTS?}

So far, this Comment has primarily dealt with the sources of law that limit tribal courts' exercise of personal jurisdiction over defendants. Once a tribe has made a determination that it has personal jurisdiction over a defendant, the next question is whether that defendant is able to challenge that determination. A defendant may choose (1) to challenge personal jurisdiction in the tribal court itself, ${ }^{165}$ (2) to default and challenge collaterally when the plaintiff seeks to enforce the judgment, ${ }^{166}$ or (3) to seek an injunction in federal court to enjoin the tribal court proceedings. I assume the first two options are available and am more concerned in this Comment with the third of these

164 See supra Part II (arguing that courts should interpret the ICRA as a limitation on personal jurisdiction).

${ }^{165}$ For instance, a tribe may provide for a special appearance, which allows a defendant to appear in court to challenge only personal jurisdiction (and sometimes subject matter jurisdiction as well), without having been deemed to have waived any objection to personal jurisdiction by appearing generally. See FrIEDENTHAL ET AL., supra note $28, \S 3.26$. Additionally, a tribal court system may allow challenges to jurisdiction on appeal. Cf. FED. R. CIV. P. 12(b) (2) (allowing a defendant's challenge to personal jurisdiction before she answers the complaint to preserve any objection to jurisdiction).

${ }^{166}$ This type of collateral challenge would occur if a plaintiff tried to enforce a tribal court judgment in a non-tribal court. See Friedenthal ET AL., supra note 28, $\S 3.26$ ("[T] he defendant need not appear at all, and, if judgment is entered on the basis of invalid service or improper jurisdiction, jurisdiction may be attacked collaterally in any action brought to enforce the defective judgment." (citation omitted)). 
options, which perhaps is more peculiar to litigation in tribal courts. ${ }^{167}$ To analyze whether a federal court should have power to enjoin a tribal court based on the latter's exercise of personal jurisdiction, I will first summarize briefly the current standard for challenging tribal court subject matter jurisdiction and explain why it is inapplicable to challenging personal jurisdiction. Second, assuming that Santa Clara Pueblo v. Martinez does not completely foreclose the possibility of an implied right of action under the ICRA ${ }^{168}$ I will discuss why the ICRA should not be read to create an implied cause of action to challenge personal jurisdiction.

\section{A. The Current Standard for Challenging Jurisdiction}

In National Farmers Union Insurance Cos. v. Crow Tribe, the Supreme Court held that there is a federal cause of action to vindicate the "right to be protected against an unlawful exercise of Tribal Court judicial power." ${ }^{169}$ The Court noted that it did not need an actual statute to create a cause of action, because the nature of Congress's plenary power governed how much sovereignty had been divested from the tribes. ${ }^{170}$ Thus, the Court stated that the federal issue to be decided was whether the "tribe retains the power to compel a nonIndian property owner to submit to the civil jurisdiction of a tribal court." ${ }^{, 71}$ The Court held that exhaustion of tribal remedies was required in order to give the tribal court the first chance to assess the factual and legal bases for the challenge to its jurisdiction. ${ }^{172}$

The method of analysis the Court undertook in National Farmers can be characterized in two steps: First, is there a statute that governs this question? Second, if not, is there a source of federal law that creates a cause of action? ${ }^{173}$ In National Farmers, there was no statute on point, but Congress had the plenary power to diminish tribal sovereignty, even if it had not exercised its power to do so through any leg-

${ }^{167}$ See FRIEDENTHAL ET AL., supra note 28, § 3.26 (discussing how the other two options operate in federal and state courts).

168436 U.S. 49 (1978).

169 471 U.S. $845,850-53$ (1985).

${ }^{170} \mathrm{Id}$. at $850-51$.

171 Id. at 852 .

${ }^{172}$ Id. at 856-57; accord Iowa Mut. Ins. Co. v. LaPlante, 480 U.S. 9, 17 (1987) ("Until appellate review is complete, the Blackfeet Tribal Courts have not had a full opportunity to evaluate the [jurisdiction challenge] and federal courts should not intervene.").

${ }^{173}$ E.g., 28 U.S.C. $§ 1331$ (2000) (providing federal question jurisdiction to federal district courts). 
islation. Thus, the Court in National Farmers simply answered the second question in the affirmative. However, if the ICRA is the source of federal law that limits tribal exercise of personal jurisdiction, the Court should not reach the second question at all because the statute must govern. If Congress has regulated tribal courts' personal jurisdiction by the ICRA, as I have argued, then the federal cause of action to challenge such jurisdiction must come from that statute and not from the theoretical limits of Congress's plenary power. The cause of action created by National Farmers should not allow challenges to a tribal court's exercise of personal jurisdiction.

\section{B. Creating a Cause of Action To Enforce the ICRA}

A direct challenge in federal court to the tribal court's exercise of personal jurisdiction over a defendant must arise under the ICRA, which limits tribal personal jurisdiction. In Martinez, the Court, per Justice Marshall, refused to create an implied cause of action under the ICRA, and, thus, did not allow the plaintiffs to sue the tribe or its officers in federal court for violations of the ICRA's provisions. ${ }^{174} \mathrm{Be}-$ fore analyzing the case under the four Cort $v$. Ash ${ }^{175}$ factors, the Court first noted that providing a federal forum to vindicate rights under the ICRA would interfere with tribal autonomy by subjecting "a dispute arising on the reservation among reservation Indians to a forum other than the one they have established for themselves."

In a footnote, the Martinez Court listed the four Cort factors: (1) whether the plaintiff was part of the intended class of beneficiaries, (2) whether Congress intended to create or deny a remedy, (3) consistency between such a remedy and the underlying purpose of the legislative scheme, and (4) whether the cause of action is traditionally relegated to tribal law. ${ }^{177}$ However, the Court virtually ignored all of these factors save the third one, which it analyzed in great detail. It found that because Congress had the dual purposes of promoting tribal sovereignty and protecting individual rights through the entire

${ }^{174}$ Santa Clara Pueblo v. Martinez, 436 U.S. 49, $51-52$ (1978); see also id. at 65 ("Tribal forums are available to vindicate rights created by the ICRA, and $\S 1302$ has the substantial and intended effect of changing the law which these forums are obliged to apply.").

${ }^{175} 422$ U.S. 66 (1975)

${ }^{176}$ Martinez, 436 U.S. at 59 (quoting Fisher v. Dist. Ct., 424 U.S. 382, 387-88 (1976)) (emphases added).

${ }^{177}$ Id. at 60-61 n.10; Cort, 422 U.S. at 78. The Martinez Court substituted tribal law for state law in the fourth factor. 
statutory scheme, it would not have created an implied cause of action that benefited one purpose at the expense of the other. ${ }^{178}$ In dissent, Justice White forcefully argued that Congress did not intend to create substantive federal rights only to deny a federal forum to enforce those rights, especially since one of the ills that prompted the passage of the ICRA was the lack of remedies for individual Indians against tribal deprivation of their civil rights. ${ }^{179}$

However, even using Justice Marshall's characterization of the interests involved, Martinez is distinguishable from cases where the defendant is a nonmember, on the ground that its concern-that federal court review of wholly internal tribal matters impedes the other purposes of the statute-is inapposite. If a defendant is a member of the tribe living on the reservation, then the tribal court should generally be able to acquire personal jurisdiction over her because she resides within territory under tribal control. However, if the defendant is a nonmember living off the reservation, then the tribe would not be able to acquire jurisdiction simply because of the location of residence or membership, and thus the matter at issue is not wholly internal to the tribe. ${ }^{180}$ Distinguishing Martinez to show that it does not foreclose the possibility of an implied cause of action is only the first step, though. ${ }^{181}$

The second, and arguably much more important, step is to determine whether the Court should create an implied cause of action. Here the Cort analysis has been eclipsed by subsequent authority on when the Court should imply a personal right of action. The question is not whether there should have been an implied cause of action in 1978 (when Martinez was decided using the Cort factors) or even 1968 (when the ICRA was enacted), but rather in 2006. In Alexander $v$. Sandoval, the current controlling authority, the Court refused to use

178 Martinez, 436 U.S. at 64.

${ }^{179} I d$. at 79-80 (White, J., dissenting); see also supra Part II.B (discussing the legislative history of the ICRA).

${ }^{180}$ A sticky issue might arise when a tribe tries to exercise personal jurisdiction over a nonconsenting member who lives off the reservation, in which case one might still classify the issue as one of internal management. However, I am more concerned with the types of cases discussed in Part III, where the defendant is not a member of the tribe and does not reside on the reservation.

${ }^{181}$ Of course, if a court found Martinez controlling and indistinguishable, it would simply refuse to create a cause of action to challenge personal jurisdiction under the ICRA. 
the "contemporary legal context" and instead looked directly to the text and structure of the statute to find congressional intent. ${ }^{182}$

Nowhere does the ICRA even suggest that there should be a federal cause of action to challenge violations of due process by tribal governments, ${ }^{183}$ nor does any other federal statute create such a cause of action. Indeed, as the Martinez Court noted in 1976, "providing a federal forum for issues arising under $\S 1302$ constitutes an interference with tribal autonomy and self-government beyond that created by the change in substantive law itself." 184 Tribal court systems have grown substantially over the past three decades, ${ }^{185}$ and allowing federal courts to hear direct challenges to tribal court personal jurisdiction would cause an even greater incursion into tribal self-government than it would have in 1976.

In addition, Congress has provided a cause of action for violations of federal civil rights under color of state law, which has been in the U.S. Code for over a century. ${ }^{186}$ Presumably, Congress is well aware of how to create a similar cause of action for Indian tribes and has chosen not to do so. ${ }^{187}$ Until Congress acts, it is unlikely that the Court, especially as currently constituted, will create a cause of action. ${ }^{188}$ Furthermore, there is simply no need to create a cause of action that would disrupt tribal court litigation unless there is some finding that tribal courts are not competent. Such a finding would run counter to the cases discussed in Part III.

182532 U.S. 275, 287-88 (2001). By “contemporary," the Court is referring to when the law was passed, not when the Court decided the case.

${ }^{183}$ Martinez, 436 U.S. at 51-52 ("Title I of the ICRA does not expressly authorize the bringing of civil actions for declaratory or injunctive relief to enforce its substantive provisions.").

${ }^{184}$ Id. at 59.

${ }^{185}$ See supra note 5 and accompanying text.

18642 U.S.C. $\$ 1983$ (2000).

187 Cf. Bivens v. Six Unknown Named Agents of Fed. Bureau of Narcotics, 403 U.S. 388, 427-28 (1971) (Black, J., dissenting) (noting that Congress could create a cause of action against federal agents for violating federal civil rights parallel to 42 U.S.C. $\S$ 1983 , if it so desired, but since it had not, no such action should be implied).

${ }^{188}$ Of course, the Supreme Court's current skepticism toward the effectiveness of tribal governments may override its concern about creating a cause of action in the absence of congressional action. See Krakoff, supra note 155, at 1178 (noting that the Court ruled against tribal interests, at least in part, in twenty-three of twenty-nine cases from 1991 to 2001). 


\section{CONCLUSION}

In this Comment, I have attempted to sketch out the limits on tribal courts' exercise of personal jurisdiction over nonconsenting defendants. Just as the Due Process Clauses of the Fifth and Fourteenth Amendments constrain the exercise of personal jurisdiction by federal and state courts, the Due Process Clause of the ICRA, which was enacted as a parallel to those amendments, should bind tribal courts to the conception of modern personal jurisdiction. Furthermore, Congress has both chosen to limit the exercise of personal jurisdiction through the ICRA and chosen not to create a federal cause of action to challenge tribal courts' violations of the ICRA. Given that Congress is the branch of government that has plenary power over Indians, the federal courts should not take it upon themselves to create a cause of action that would allow litigants to circumvent the tribal court process.

At its heart, personal jurisdiction is about fundamental fairness to the litigants. Tribal courts have been disparaged as unable to provide fair and just litigation for far too long. Yet they are required by the federal government to provide due process, and a brief selection of some of their opinions indicates that they have the capacity to do so. A functioning judicial branch is a key element of true sovereignty. It is imperative that the federal government, especially the judiciary, protect Congress's long-standing policy of promoting tribal sovereignty. Americans must trust the tribal court system to mete out the same justice as would be expected from any other court. 